\title{
The Potential for Methane Emissions from Groundwaters of the UK
}

\author{
D C Gooddy* and W G Darling
}

British Geological Survey, Wallingford, Oxfordshire, OX10 8BB, UK

$\begin{aligned}{ }^{*} \text { Corresponding author: } & \text { phone }+44(0) 1491692328 \\ & \text { fax } \quad+44(0) 1491692345 \\ & \text { e-mail } \underline{\text { dcg@ } \text { bgs.ac.uk }} \\ & \text { Dr Daren C Gooddy } \\ & \text { Maclean Building } \\ & \text { British Geological Survey } \\ & \text { Crowmarsh Gifford, Wallingford } \\ & \text { Oxfordshire, OX10 8BB, UK }\end{aligned}$

\section{ABSTRACT}

Methane $\left(\mathrm{CH}_{4}\right)$ is only a trace constituent of the atmosphere but an important greenhouse gas. Although groundwater is unlikely to be a major source of atmospheric $\mathrm{CH}_{4}$, its contribution to the $\mathrm{CH}_{4}$ budget of the UK has up to now been poorly characterised. Groundwater $\mathrm{CH}_{4}$ concentrations have been measured on 85 samples from water-supply boreholes and a further eight from other miscellaneous water sources. Concentrations in abstracted groundwaters ranged from $<0.05-42.9 \mu \mathrm{g} / 1$ for Chalk, $<0.05-22 \mu \mathrm{g} / 1$ for the Lower Greensand, $0.05-$ $21.2 \mu \mathrm{g} / \mathrm{l}$ for the Lincolnshire Limestone and from $<0.05-465 \mu \mathrm{g} / \mathrm{l}$ for the Permo-Triassic sandstone. Having the largest abstraction volume, the Chalk is likely to be the main UK groundwater contributor to global $\mathrm{CH}_{4}$ emissions. A calculation to estimate the total emissions of $\mathrm{CH}_{4}$ from water supply groundwater sources based on the median and the maximum $\mathrm{CH}_{4}$ concentrations gave a values of $2.2 \times 10^{-6} \mathrm{Tg} / \mathrm{yr}$ and $3.3 \times 10^{-4} \mathrm{Tg} / \mathrm{yr}$. Estimates show groundwater contributes a maximum of $0.05 \%$ of all $\mathrm{UK} \mathrm{CH}_{4}$ emissions and a further two orders of magnitude less in terms of the global $\mathrm{CH}_{4}$ budget. Other groundwater sources such as inflows to tunnels may have significantly higher $\mathrm{CH}_{4}$ concentrations, but the volume of water discharged is much lower and the overall amount of $\mathrm{CH}_{4}$ outgassed is likely to be of the same order as the aquifer release. The generally low concentrations of $\mathrm{CH}_{4}$ in groundwater supplies suggest no threat of explosion, although groundwater released by excavations remains a hazard.

Key Words: Methane $\left(\mathrm{CH}_{4}\right)$, Groundwater, Emissions, UK, Explosion hazard. 


\section{INTRODUCTION}

Methane $\left(\mathrm{CH}_{4}\right)$ has both general and local impacts on the environment. On the one hand it is a greenhouse gas, some 20 times more potent than $\mathrm{CO}_{2}$ (US EPA, 2002), while on the other it poses a potential explosive threat when build-up occurs in confined spaces (Hooker and Bannon, 1993).

The role played by groundwater in both the above areas has been poorly understood for the UK. Admittedly it has never seemed likely that $\mathrm{CH}_{4}$ originating in, or transported by, groundwater would be a major source of greenhouse $\mathrm{CH}_{4}$ or a widespread explosion hazard, yet information on baseline concentrations has not hitherto been available to confirm this. The present study examines $\mathrm{CH}_{4}$ concentration data from three types of source (major watersupply aquifers, igneous and metamorphic rocks, and high-methane waters) to characterise the groundwater $\mathrm{CH}_{4}$ inventory rather better. To do this 93 samples have been analysed and interpreted. The potential contribution of groundwater $\mathrm{CH}_{4}$ to the global carbon budget has been assessed.

\section{BACKGROUND}

Origins of methane

Methane is a common trace component in groundwater and occasionally constitutes a major carbon pool (Barker and Fritz, 1981; Cramer et al., 1999; Geyh and Künzl, 1981; Parkin and Simpkins, 1995; Watanabe et al., 1994). Methane of varying origins can accumulate in nearsurface groundwaters: abiogenic $\mathrm{CH}_{4}$ has been identified in groundwater in the Canadian Shield (Sherwood et al., 1988); in ophiolite terrains (Neal and Stanger, 1983); and in midocean ridges (Welhan, 1988). Thermogenic $\mathrm{CH}_{4}$ (produced by thermal decomposition of organic matter) is associated with coal, oil or gas fields (Tissot and Welte, 1984), or indeed any situation where organic-rich sediments are thermally stressed (Simoneit et al., 1988). Biogenic $\mathrm{CH}_{4}$ (bacterially-produced) has been found in marine environments (Schoell, 1988) and anaerobic groundwater environments, including peat bogs, lignite deposits, and glacial, lacustrine and aeolian sediment (Barker and Fritz, 1981; Coleman et al., 1988; Grossman et al., 1989). The concentration of $\mathrm{CH}_{4}$ in natural waters can range from $<1-15,000 \mu \mathrm{g} / 1$ which reflects its variation in source from anaerobic environments (Thurman, 1985). 
Abiogenic $\mathrm{CH}_{4}$ is not an issue for the $\mathrm{UK}$; thermogenic $\mathrm{CH}_{4}$ may be a local factor, but the most widespread production of the $\mathrm{CH}_{4}$ found in groundwater is likely to be biogenic.

\section{Methanogenesis}

Methanogenesis is a complex process and can proceed via several possible metabolic pathways and use several possible substrates. The two major metabolic pathways are acetate fermentation,

$\mathrm{CH}_{3} \mathrm{COOH} \rightarrow \mathrm{CH}_{4}+\mathrm{CO}_{2}$

and $\mathrm{CO}_{2}$ reduction,

$\mathrm{CO}_{2}+4 \mathrm{H}_{2} \rightarrow 2 \mathrm{H}_{2} \mathrm{O}+\mathrm{CH}_{4}$

Methanogenesis represents the last of a series of reactions where electron acceptors such as $\mathrm{O}_{2}, \mathrm{NO}_{3}{ }^{-}, \mathrm{Mn}^{4+}, \mathrm{Fe}^{3+}$ and $\mathrm{SO}_{4}{ }^{2-}$ are used sequentially to oxidise organic matter. Conditions most favourable to biogenic $\mathrm{CH}_{4}$ formation are found in anaerobic and low Eh environments, such as confined groundwaters (Bishop and Lloyd, 1990), groundwaters from beneath rapidly developing cities (Lawrence et al., 2000) and, in particular, leachates beneath landfill sites (Christensen et al., 2001) and organic waste stores (Gooddy et al., 2002) where a usable substrate exists to provide energy. However, under the well-oxygenated conditions typical of unconfined aquifers, methanogenesis would not be expected to be a major process.

\section{Groundwaters in the UK}

The habitats of groundwater in the UK vary considerably, from low-permeability mudrocks to the minimal porosities of crystalline (igneous and metamorphic) rocks, and ultimately the relatively high porosities of the water supply aquifers of (mainly) the south and east. Each of these habitats has different implications for $\mathrm{CH}_{4}$ production and ultimately emissions to the atmosphere.

\section{Main aquifers}

Groundwater meets over 30\% of the water demand in England and Wales (DETR, 1997), 8\% in Northern Ireland and 5\% in Scotland (Bell et al., 1997). The regional differences reflect the distribution of aquifers and the more favourable geological conditions for surface water resource development in the most northern parts of the UK. Four aquifers - the Chalk, Permo- 
Triassic sandstone, Lower Greensand and Lincolnshire Limestone - provide almost all groundwater in the UK (see Table 1) accounting for 95\% of abstractions (Downing, 1993).

The Chalk aquifer is the most important in the UK since it accounts for more than half of the groundwater used. It outcrops largely in the south-east of England where population density is high, rainfall is low and there are few sites for suitable surface reservoirs. The Lower Greensand also forms an important aquifer in south-east England. Despite the relatively small outcrop area of the aquifer, the high storage and generally good quality of water render it a reliable source of water for domestic and industrial use. The Permo-Triassic sandstones form the second most important aquifer in the UK, supplying around a quarter of licensed groundwater abstractions. The aquifer provides important groundwater resources, especially in central and northern England where a number of large towns depend on it for their water supplies. The Lincolnshire Limestone is important only in eastern England but is the most hydrogeologically significant part of the Jurassic limestones.

In each of these aquifers redox conditions vary depending on the degree of confinement of the aquifer, with the extent of transition zones depending critically on the degree to which local flow systems are developed and the nature of the aquifer: for example, the welldeveloped fracture porosity of the Chalk and Lincolnshire Limestone promotes a greater degree of mixing between waters than is found in the sandstone aquifers (Darling et al., 1997).

When evaluating $\mathrm{CH}_{4}$ emissions from these aquifers, consideration must be given to their discharge characteristics. In their natural state, prior to perhaps 150 years ago, any discharge from aquifers would have occurred via springs, or baseflow to rivers, or beneath the sea. Since then, the widespread development of supplies based on groundwater has distorted the natural state to an unknown extent. Many uncertainties remain regarding the total amount of discharge; the only semi-reliable data relate to the amount of groundwater abstracted.

\section{Crystalline rocks}

The so-called 'hard rocks' do not hold extensive groundwater resources and are generally used only for local domestic water supplies. Relatively high concentrations of $\mathrm{CH}_{4}$ have occasionally been recorded from groundwaters of shield areas such as Canada and Sweden, but the $\mathrm{CH}_{4}$ is most likely to have come from overlying Quaternary drift (Barker and Fritz, 1981). The possibility of 'deep' $\mathrm{CH}_{4}$ emanating from crystalline rocks (Gold, 1998) has been 
considered in some detail but has been ruled out for the UK (Bath et al., 1986). The hard-rock data considered here were obtained from inflows to hydro-electric tunnels in the Scottish Highlands. Most of these inflows are at a considerable depth below the land surface and therefore should contain representative concentrations of any $\mathrm{CH}_{4}$ produced in situ or otherwise acquired.

\section{Mudrocks}

Owing to their low permeability, the natural discharge of groundwaters from mudrocks is likely to be a very small proportion of the UK total. The generally poor quality of such groundwaters means they are rarely abstracted for water supply purposes. However, such rocks are sometimes tunnelled for water transfer between catchments, either for water supply or hydroelectric purposes, or for more general civil engineering reasons. The often high organic content of mudrocks, together with the slow rate of water movement through them, promotes the development of elevated dissolved $\mathrm{CH}_{4}$ concentrations. Only when these waters are artificially released by tunnelling or other excavation can they be recognised.

\section{Solubility and explosion hazard}

Methane is a moderately soluble gas (Wilhelm et al., 1977). Under a typical atmospheric concentration of 1.75 parts per million by volume (IPCC, 2001), the amount of $\mathrm{CH}_{4}$ dissolved in water at $10^{\circ} \mathrm{C}$ (typical UK recharge temperature) is some $7.9 \times 10^{-6} \mathrm{cc}(\mathrm{STP})$ per litre at equilibrium. This is equivalent to a concentration of $0.056 \mu \mathrm{g} / \mathrm{l}$.

However, if the local concentration of $\mathrm{CH}_{4}$ within the subsurface rises above the atmospheric partial pressure of $\sim 1.75 \times 10^{-6}$ bars, the amount of dissolved $\mathrm{CH}_{4}$ will increase proportionally. Should this water become exposed to the atmosphere, equilibrium will be reestablished and $\mathrm{CH}_{4}$ will be outgassed until the extremely low background composition is reached. From the explosion hazard point of view, the consequences of this are most significant where discharge occurs into a confined space, for example a building or excavation.

Methane becomes an explosion hazard at concentrations of $5-15 \%$ by volume in air (Hooker and Bannon, 1993). Since confined spaces vary both in their size and degree of ventilation, no universal rules can be applied to what may constitute a hazardous dissolved concentration in individual cases. However, if $\mathrm{CH}_{4}$ exceeds $5 \%$ by volume of the gases dissolved in a groundwater, and the sum of these gas partial pressures is greater than 
atmospheric, there is a potential for $\mathrm{CH}_{4}$ to outgas and reach or exceed the lower explosive limit. To put this in terms of concentration, a minimum $\mathrm{CH}_{4}$ partial pressure in excess of 0.05 bars would be required, equivalent to a value of approximately $1600 \mu \mathrm{g} / \mathrm{l}$.

A more detailed consideration of $\mathrm{CH}_{4}$ release rates, ventilation and accumulation is provided in Hooker and Bannon (1993).

\section{SAMPLING AND ANALYSIS}

The locations of sampling sites referred to in this study are shown in Figure 1. Samples of groundwater were collected over a period of time by a variety of methods, all ultimately relying on the outgassing of a known amount of water into a headspace of known volume. The partitioned headspace gas was analysed by gas chromatography using a $2 \mathrm{~m}$ column containing Porapaq-Q held isothermally at $25^{\circ} \mathrm{C}$. Helium at a flow rate of $30 \mathrm{ml} / \mathrm{min}$ was used as a carrier gas and detection was by flame ionisation. Certified canned gas standards were run with the samples in order to calibrate the results. Ultimately a detection limit of $0.05 \mu \mathrm{g} / \mathrm{l}$ was achieved by using this approach.

\section{RESULTS}

\section{Main aquifers}

A statistical summary of $\mathrm{CH}_{4}$ data for 85 groundwater samples collected from the four major aquifers in the UK is shown in Table 2. Concentrations are below $10 \mu \mathrm{g} / \mathrm{l}$ for $95 \%$ of Chalk samples, $92 \%$ of Permo-Triassic sandstones, $89 \%$ of Lincolnshire Limestones and $65 \%$ of the Lower Greensand. In terms of the median values, Lower Greensand > Lincolnshire Limestone $>$ Chalk $>$ Permo-Triassic sandstone. Mean groundwater concentrations however exhibit a slightly different trend with Permo-Triassic sandstone > Lower Greensand > Lincolnshire Limestone $>$ Chalk. In the case of the Permo-Triassic sandstone the relatively high mean value is the result of one very high concentration taken from a confined part of the aquifer and so may not be representative of methane concentrations in this aquifer as a whole. For this reason, subsequent calculations use the median concentration rather than the mean.

Figure 2 shows cumulative frequency plots for the four main aquifers and demonstrates that the data for three of the aquifers is normally or log normally distributed. Data from the Permo-Triassic sandstone suggest that there are possibly two or three populations: one below the detection limit, a second between 1 and $3 \mu \mathrm{g} / 1$ and possibly a third population with 
concentrations greater than $10 \mu \mathrm{g} / \mathrm{l}$. Although there is a paucity of data for the Permo-Triassic aquifer, Figure 2 acts as an indicator of possible trends within the data-set.

\section{Crystalline rocks}

Table 3 shows $\mathrm{CH}_{4}$ concentration data for four sites in Scotland: two in Caledonian granodiorites and two in metasediments of Precambrian and Dalradian age. Methane at three of the sites was below detection, and only just above at the remaining site. These values are little different from the equilibrium concentration of $\mathrm{CH}_{4}$ expected for water in contact with the atmosphere.

\section{High-methane waters}

As mentioned earlier, moderately high $\mathrm{CH}_{4}$ concentrations are found where groundwaters are most reducing, normally in confined conditions. Such conditions are often accompanied by sluggish or even no discernible water circulation: an example of the former is found in the down-dip portion of the Lincolnshire Limestone, while the latter occurs in the concealed Triassic sandstone strata of the Wessex Basin (Table 4). Strongly-reducing waters tend not to be exploited except for very specific purposes such as geothermal heating, and natural discharges are likely to be minimal.

The highest $\mathrm{CH}_{4}$ concentrations, however, appear to be associated with the tunnelling of mudrocks. Figure 3 shows results obtained from inflows within two transfer tunnels, Carsington (data from Pearson \& Edwards, 1991), and Wyresdale (data from Bath et al., 1988), both excavated in Namurian strata. Amounts of methane in solution reach peaks of 15,000 and $13,000 \mu \mathrm{g} / \mathrm{l}$ in the respective tunnels, equivalent to some 20 and $180 \mathrm{cc}$ STP per litre of water. These concentrations equate to $\mathrm{CH}_{4}$ partial pressures of approximately 0.5 and 4 bars respectively.

\section{DISCUSSION}

\section{Methane Formation}

Biogenic methane formation is the most likely source in these aquifers and so it is reasonable to expect the $\mathrm{CH}_{4}$ concentration to be in part explained by the availability of organic carbon undergoing methanogenesis. However, there is a lack of published data for the organic carbon content of UK aquifers. Harrold et al. (2003) provide some values for Chalk and Permo-Triassic sandstones reporting organic carbon concentrations as between $0.1-0.2 \%$ for 
the Chalk and $<0.05-0.07 \%$ for the sandstones. This probably explains the generally low methane values observed in these aquifers and may even provide an explanation as to the observed higher median methane concentrations in the Chalk compared with the PermoTriassic sandstone (Table 2). The origin of methane in English groundwaters is the subject of a further study (Darling \& Gooddy, in preparation).

\section{Calculation of methane emissions}

Indirect emissions of nitrous oxide from regional aquifers have previously been determined by Hiscock et al. (2003). This study has used a similar approach by obtaining estimates for annual abstraction from each of the aquifers ( $\mathrm{m}^{3} / \mathrm{yr}$ ) (Downing, 1993), converting this to $1 / \mathrm{yr}$ $\left(\mathrm{m}^{3} \times 10^{3}\right)$, multiplying this value by the mean, median or maximum methane concentration for each aquifer type $(\mu \mathrm{g} / \mathrm{l})$ and finally converting this to $\mathrm{Tg} / \mathrm{yr}\left(\mu \mathrm{g} \times 10^{-18}\right)$. The method assumes that the methane will completely outgas once it has been abstracted which is likely to lead to an over-estimation of methane emissions.

Table 5 shows the total emissions of methane based on abstraction volumes from each of the four aquifer types. On this basis the Chalk groundwaters are the greatest source of methane owing to the much higher abstraction volumes. For each of the aquifers there will be an element of natural discharge, which might perhaps double the abstraction emissions.

Groundwater in crystalline rocks appears to contribute nothing of significance to $\mathrm{CH}_{4}$ emissions, which is fortunate since any figure for discharge would be highly speculative. However, high- $\mathrm{CH}_{4}$ groundwater discharges, though small in volume are orders of magnitude higher in concentration than potable water sources (Figure 2). These outputs are not well characterised but it is conceivable that emissions are of the same order as those from the major aquifers.

By summing the calculated methane emissions from groundwater abstraction volumes and the maximum measured methane concentrations; an equal amount of emissions resulting from natural discharge; and an equal amount from high $\mathrm{CH}_{4}$ groundwater discharges that are very low in volume, the total $\mathrm{CH}_{4}$ emission from UK groundwaters might therefore total 1.0 x $10^{-3} \mathrm{Tg} \mathrm{CH}_{4} / \mathrm{yr}$ (i.e. 3 times as much as the calculated maximum abstraction emission). Based on the values of Salway et al. (2002) who estimated a total UK emission of $2.2 \mathrm{Tg}$ $\mathrm{CH}_{4} / \mathrm{yr}$, the groundwater contribution accounts for no more than $0.05 \%$ of this. To put this contribution into context, $\mathrm{UK} \mathrm{CH}_{4}$ emissions are mostly accounted for by agricultural 
activities (37\%), followed by landfill (22\%), gas leaks (16\%) and coal mines (11\%) (Salway et al., 1994). In terms of a global methane budget of $587 \mathrm{Tg} \mathrm{CH}_{4} / \mathrm{yr}$ (Hein et al., 1997) the methane contribution from UK groundwaters is a further two orders of magnitude lower.

\section{Methane Hazards}

It is clear from the data summarised above that most groundwaters in the UK, potable or otherwise, have $\mathrm{CH}_{4}$ contents orders of magnitude below the theoretical $1600 \mu \mathrm{g} / 1$ that is necessary to reach the lower explosive limit after outgassing in a confined space. In reality it is likely that significantly higher $\mathrm{CH}_{4}$ concentrations are required before an explosion hazard results. Such waters do exist in aquifers where conditions are suitably reducing: the examples from the down-gradient Lincolnshire Limestone aquifer and the concealed Sherwood Sandstone are cases in point. In particular, however, it is the waters from organic-rich formations generally regarded as aquitards that pose the greatest risk when pressure is released by excavation, in particular tunnelling. Fortunately this risk is now well recognised so that the appropriate measures can be taken (Hooker and Bannon, 1993).

\section{CONCLUSIONS}

Samples of groundwater from a range of rock types across the UK have been analysed for their methane content. Even using 'worst case' estimates of groundwater-derived emissions, it is clear from the data that such sources cannot be a significant contributor to the UK, let alone global, methane budget.

Nevertheless, against the generally low background concentrations typical of the UK's main aquifers certain instances of very high methane waters stand out. These hazardous emissions are usually associated with Upper Carboniferous strata, but it is highly probable that tunnelling in organic-rich clays of any age would produce a similar outcome.

\section{Acknowledgements}

The authors are grateful to colleagues who have collected methane samples over the past two decades. This paper is published with the permission of the Executive Director, British Geological Survey (NERC). 


\section{REFERENCES}

Barker JF, Fritz P. The occurrence and origin of methane in some groundwater flow systems. Can J Earth Sci 1981; 18: 1802-1816.

Bath AH, Brassell SC, Eglinton G, Hill RI, Hooker PJ, O’Nions RK, Oxburgh ER, Parnell J, Robinson N, Spiro B. Deep source gases and hydrocarbons in the UK crust. BGS Rep FLPU 86-2: 1986.

Bath AH, Darling WG, Hitchman SP, Andrews JN, Cave MR, Green KA, Reeder S. Chemical and stable isotopic analyses of dissolved gases and groundwater seepages collected from Wyresdale Tunnel, November 1987. BGS Rep WE/88/1: 1988.

Bell DF, McDonald AM, Morris BL, Lilly A. Scotland's Minor Aquifers: A Scoping Study to Assess Groundwater Source Protection. BGS Rep WD/97/63: 1997.

Bishop PK, Lloyd JW. Chemical and isotopic evidence for the hydrogeological processes occurring in the Lincolnshire Limestone. J Hydrol 1990; 121: 293-320.

Coleman DD, Liu C-L, Riley KM. Microbial methane in the shallow Paleozoic sediments and glacial deposits of Illinois. Chem Geol 1988; 71: 23-40.

Christensen TH, Kjeldsen P, Bjerg PL, Jensen DL, Christensen JB, Baun A, Albrechtsen HJ, Heron C. Biogeochemistry of landfill leachate plumes. Appl Geochem 2001; 16: 659718.

Cramer B, Poelchau HS, Gerling P, Lopatin NV, Littke R. Methane released from groundwater: the source of natural gas accumulations in northern West Siberia. Mar Pet Geol 1999; 16: 225-244.

DETR. Digest of Environmental Statistics. Department of the Environment, Transport and the Regions. London: TSO 1997.

Darling WG, Edmunds WM, Smedley PL. The isotopic composition of palaeowaters in the British Isles. Appl Geochem 1997; 12: 813-829.

Darling WG, Gooddy DC. The hydrogeochemistry of methane: evidence from English groundwaters (in prep). 
Downing RA. Groundwater resources, their development and management in the UK: an historical perspective. Q J Eng Geol 1993; 26: 335-358.

Geyh MA, Kunzl R. Methane in groundwater and its effect on ${ }^{14} \mathrm{C}$ groundwater dating. $\mathrm{J}$ Hydrol 1981; 52: 355-358.

Gold T. The Deep Hot Biosphere. Copernicus, New York, 1998.

Gooddy DC, Clay JW, Bottrell SH. Redox-driven changes in pore-water chemistry of the Chalk unsaturated zone beneath unlined cattle slurry lagoons. Appl Geochem 2002; 17: 903-921.

Grossman EL, Coffman BK, Fritz SJ, Wada H. Bacterial production of methane and its influence on ground-water chemistry in east-central Texas aquifers. Geol 1989; 17: 495-499.

Harrold G, Gooddy DC, Reid S, Lerner DN, Leharne SA. Changes in interfacial tension of chlorinated solvents following flow though UK soils and shallow aquifer material. Environ Sci Technol 2003; 37: 1919-1925.

Hein R, Crutzen PJ, Heinmann M. An inverse modeling approach to investigate the global atmospheric methane cycle. Global Biogeochem Cycles 1997; 11: 43-76.

Hiscock KM, Bateman AS, Muhlherr I, Fukada T, Dennis PF. Indirect emissions of nitrous oxide from regional aquifers in the United Kingdom. Environ Sci Technol 2003; 37: $3507-3512$.

Hooker PJ, Bannon MP. Methane: its occurrence and hazards in construction. CIRIA Publication R130, 140 pp. 1993.

Inter-governmental Panel on Climate Change (IPCC). Climate change: the scientific basis 2001. Cambridge University Press, Cambridge, UK 2001.

Lawrence AR, Gooddy DC, Kanatharana P, Ramnarong V, Meesilp W. Groundwater evolution beneath a rapidly developing city in south east Asia. Hydrogeol J 2000; 8: 564-575. 
Neal C, Stanger G. Hydrogen generation from mantle source rocks in Oman. Earth Planet Sci Lett 1983; 66: 315-320.

Parkin TB, Simpkins WW. Contemporary groundwater methane production from Pleistocene carbon. J Environ Qual 1995; 24: 367-372.

Pearson F, Edwards JS. Methane entry into the Carsington Aqueduct system. In: Methane Facing the problems. $2^{\text {nd }}$ Symposium, Nottingham, 4.3.1-10, 1991.

Salway AG, Murrells TP, Milne R, Ellis S. UK greenhouse gas inventory 1990 to 2000. National Environment Technology Centre, AEA Technology, Culham, 2002. ISBN 07058-1805-5

Schoell M. Multiple origins of methane in the Earth. Chem Geol 1988; 71: 1-10.

Sherwood BA, Fritz P, Frape SK, Macko SA, Weise SM, Welhan JA. Methane occurrences in the Canadian Shield. Chem Geol 1988; 71: 223-236.

Simoneit BRT, Kawka OE, Brault M. Origin of gases and condensates in the Guaymas Basin hydrothermal system (Gulf of California). Chem Geol 1988; 71: 169-182.

Thurman EM. Organic Geochemistry of Natural Waters. Martinus Nijhoff/Dr W. Junk, Dordrecht 1985.

Tissot BP, Welte DH. Petroleum Formation and Occurrence $2^{\text {nd }}$ Edition. Springer-Verlag, Berlin Heidelberg 1984.

US EPA. Inventory of US greenhouse gas emissions and sinks: 1990-2000. Rep of US Environmental Protection Agency 2002.

Watanabe A, Kimura M, Kasuya M, Kotake M, Katoh T. Methane in groundwater used for Japanese agriculture: Its relationship to other physico-chemical properties and possible tropospheric source strength. Geophys Res Lett 1994; 21: 41-44.

Welhan JA. Origins of methane in hydrothermal systems. Chem Geol 1988; 71: 183-198.

Wilhelm E, Battino R, Wilcock RJ. Low-pressure solubility of gases in liquid water, Chem Rev 1977; 77: 219-262. 
Table 1. Infiltration and abstraction of major UK aquifers in million $\mathrm{m}^{3}$ per year (after Downing, 1993)

Infiltration Abstraction in 1977

Chalk 4631

Lower Greensand

275

86

Lincolnshire Limestone

86

43

Triassic sandstone

1443

587 
Table 2. Statistical summary of methane data from potable groundwaters

\begin{tabular}{lrcrr}
\hline & Chalk & $\begin{array}{l}\text { Lower } \\
\text { Greensand }\end{array}$ & $\begin{array}{l}\text { Lincolnshire } \\
\text { Limestone }\end{array}$ & $\begin{array}{l}\text { Triassic } \\
\text { Sandstone }\end{array}$ \\
& & & & \\
Samples & 44 & 20 & 9 & 12 \\
& & & & \\
Mean $(\mu \mathrm{g} / \mathrm{l})$ & 2.81 & 7.89 & 4.42 & 39.5 \\
Median $(\mu \mathrm{g} / \mathrm{l})$ & 0.94 & 7.66 & 2.60 & 0.465 \\
Standard deviation $(\mu \mathrm{g} / \mathrm{l})$ & 7.17 & 6.27 & 6.50 & 134 \\
Minimum $(\mu \mathrm{g} / \mathrm{l})$ & $<0.05$ & $<0.05$ & 0.05 & $<0.05$ \\
Maximum $(\mu \mathrm{g} / \mathrm{l})$ & 42.9 & 22.0 & 21.2 & 465 \\
& & & & \\
Confidence level $(95.0 \%)$ & 2.18 & 2.94 & 5.00 & 85.2 \\
\hline
\end{tabular}


Table 3. Methane concentrations from crystalline rocks in Scotland

\begin{tabular}{llr}
\hline Site & Rock Type & \multicolumn{1}{c}{$\begin{array}{c}\text { Methane } \\
(\mu \mathrm{g} / 1)\end{array}$} \\
\hline Cruachan & Caledonian granodiorite & $<0.05$ \\
Foyers & Caledonian granodiorite & 0.09 \\
Glenmoriston & Moine metasediments & $<0.05$ \\
South Lawers & Dalradian metasediments & $<0.05$ \\
\hline
\end{tabular}


Table 4. High methane concentration groundwaters not from public-supply sources

\begin{tabular}{llr}
\hline Site & Rock Type & $\begin{array}{c}\text { Methane } \\
(\mu \mathrm{g} / 1)\end{array}$ \\
\hline Stow $4^{\mathrm{a}}$ & Lincolnshire Limestone & 1700 \\
Stow $6^{\mathrm{a}}$ & Lincolnshire Limestone & 2300 \\
Marchwood geothermal & Sherwood Sandstone, Southampton & 7790 \\
Western Esplanade geothermal & Sherwood Sandstone, Southampton & 5540 \\
\hline
\end{tabular}

${ }^{\mathrm{a}}$ Data from Bishop and Lloyd, 1990 
Table 5. Atmospheric emissions of methane based on abstractions from potable UK groundwaters

\begin{tabular}{lcrrrr}
\hline & $\begin{array}{c}\text { Abstraction } \\
\left(\mathrm{m}^{3} / \mathrm{yr}\right)\end{array}$ & $\begin{array}{c}\text { Methane } \\
(\mu \mathrm{g} / \mathrm{l})\end{array}$ & \multicolumn{2}{c}{$\begin{array}{c}\text { Emissions } \\
(\mathrm{Tg} / \mathrm{yr})\end{array}$} \\
\hline Chalk & & Median & Max & Median & Max \\
Lower Greensand & $1.26 \times 10^{9}$ & 0.94 & 42.9 & $1.17 \times 10^{-6}$ & $5.38 \times 10^{-6}$ \\
Lincolnshire Limestone & $4.60 \times 10^{7}$ & 7.66 & 22.0 & $6.59 \times 10^{-7}$ & $1.89 \times 10^{-6}$ \\
Triassic sandstone & $5.87 \times 10^{7}$ & 2.60 & 21.2 & $1.12 \times 10^{-7}$ & $9.12 \times 10^{-7}$ \\
& & 0.47 & 465 & $2.73 \times 10^{-7}$ & $2.73 \times 10^{-4}$ \\
SUM & $1.97 \times 10^{9}$ & & & & \\
\hline
\end{tabular}

